\title{
CLIMATE INDICATORS FOR A WATERSHED IN THE EASTERN AMAZON
}

TAVARES, Alexandra Lima - alexandra.tavares@pq.itv.org Instituto Tecnológico Vale / ITV

CARMO, Alexandre Melo Casseb do - acasseb@ufpa.br Universidade Federal do Pará / UFPA

SILVA JÚNIOR, Renato Oliveira da - renato.silva.junior@itv.org Instituto Tecnológico Vale / ITV

SOUZA-FILHO, Pedro Walfir Martins e - pedro.martins.souza@itv.org Instituto Tecnológico Vale / ITV

SILVA, Marcio Sousa da - marcio.sousa.silva@itv.org Universidade Federal do Pará / UFPA

\begin{abstract}
FERREIRA, Douglas Batista da Silva - douglas.silva.ferreira@itv.org Instituto Tecnológico Vale / ITV
\end{abstract}

NASCIMENTO JÚNIOR, Wilson da Rocha - wilson.nascimento@itv.org Instituto Tecnológico Vale / ITV

DALL'AGNOL, Roberto - roberto.dallagnol@itv.org

Instituto Tecnológico Vale / ITV

\begin{abstract}
The present study compares the climatological normals for periods of 36 and 34 years (interpolated data) and observed precipitation and air temperature data (2015 and 2016) for four weather stations located within the boundaries of the Itacaiúnas River Watershed (IRW), with the historical data from the Marabá station in the eastern Amazon used as control data. Both the interpolated and observed data were validated with the control data. The quantile technique was used to identify annual precipitation intensity thresholds and seasonal periods. A comparison was made with the precipitation and air temperature data to determine the effects of ENSO events during the period from 1980 to 2016 . Our results regarding annual variability showed that the Onça Puma station was the rainiest among the subareas studied. The month of March was characterized as the rainiest month, and July was the least rainy for the watershed area. The influence of ENSO events on air temperature occurred in the early years, from 1980 to 2003, and the stronger events had a greater influence on precipitation in the IRW area. The 2015/16 El Niño may have had a more pronounced effect on the rainfall behavior at the Fazenda Abadia and Sossego stations. In the Salobo station (forest area), there was a delay in precipitation curves related to the occurrence of ENSO events, which may be associated with temporal variations in the dynamics of soil-vegetationatmosphere interactions.
\end{abstract}

KEYWORDS: precipitation, temperature, climatology, El Niño, La Niña INDICADORES CLIMÁTICOS PARA UMA BACIA HIDROGRÁFICA NA AMAZÔNIA ORIENTAL

RESUMO: O presente estudo verificou a comparação entre as normais climatológicas de 36 e 34 anos (dados interpolados), e os dados observados (2015 e 2016) da precipitação e temperatura do ar, para quatro estações hidrometeorológicas situadas na área da Bacia Hidrográfica do Rio Itacaiúnas (BHRI), com dados históricos definidos como de controle da estação Marabá, na Amazônia oriental. Foi feita a validação tantos dos dados 
interpolados quanto dos observacionais, com os dados de controle. Foi utilizada a técnica dos quantis para identificar os limites de intensidade da precipitação anual e seus períodos sazonais. Realizou-se uma comparação da climatologia da precipitação e temperatura do ar com os efeitos dos eventos de ENOS durante o período de 1980 a 2016. Nossos resultados mostraram que a variabilidade anual da estação Onça Puma se caracterizou como a mais chuvosa entre as demais subáreas estudadas. O mês de março caracterizou-se como o mês mais chuvoso e julho o menos chuvoso para a região da bacia. A influência dos eventos ENOS com relação a temperatura do ar ocorrem nos primeiros anos, a partir de 1980 até 2003, e os tipos mais fortes destes eventos apresentam maior influência sobre a precipitação na região da BHRI. O efeito do EN 2015/16 pode ter influenciado de forma mais acentuada no comportamento das chuvas nas estações Fazenda Abadia e Sossego. Foi observado na estação Salobo (área florestada) um certo atraso nas curvas de precipitação com relação às ocorrências dos eventos ENOS, que pode estar associado a variações temporais na dinâmica de interação solo-vegetação-atmosfera.

PALAVRAS-CHAVE: Precipitação, temperatura, climatologia, El Niño, La Niña.

\section{INDICADORES CLIMÁTICOS PARA UNA CUENCA EN EL AMAZON ESTE}

RESUMEN: El presente estudio compara las normales climatológicas para períodos de 36 y 34 años (datos interpolados) y los datos observados de precipitación y de temperatura del aire (2015 y 2016) para cuatro estaciones meteorológicas ubicadas dentro de los límites de la Cuenca del Río Itacaiúnas (CRI), se usaron como control los datos históricos de la estación de Marabá, en la Amazonía oriental. Tanto los datos interpolados como los observados fueron validados con los datos de control. La técnica de cuantiles se utilizó para identificar los umbrales de intensidad de precipitación anual y los períodos estacionales. Se hizo una comparación con los datos de precipitación y temperatura del aire para determinar los efectos de los eventos ENOS durante el período de 1980 a 2016. Nuestros resultados mostraron que la variabilidad anual de la estación Onça Puma fue la más lluviosa entre las subáreas estudiadas. El mes de marzo se caracterizó como el mes más lluvioso y julio fue el menos lluvioso en el área de la cuenca. La influencia de los eventos ENOS en relación a la temperatura del aire ocurrió en los primeros años, de 1980 a 2003, y los eventos más fuertes tuvieron una mayor influencia en la precipitación en la región CRI. El Niño de 2015/16 puede haber tenido un efecto más pronunciado en el comportamiento de la lluvia en las estaciones de Fazenda Abadia y Sossego. En la estación de Salobo (área forestal), hubo un retraso en las curvas de precipitación relacionadas con la ocurrencia de eventos ENOS, que pueden estar asociados con variaciones temporales en la dinámica de las interacciones suelo-vegetación-atmósfera.

PALABRAS CLAVE: precipitación, temperatura, climatología, El Niño, La Niña

\section{INDICATEURS CLIMATIQUES POUR UN BASSIN HYDROGRAPHIQUE EN AMAZON EST}

RÉSUMÉ: La présente étude compare les normales climatologiques pour les périodes de 36 et 34 ans (données interpolées) et les données de précipitations et de température de l'air observées (2015 et 2016) pour quatre stations météorologiques situées dans les limites du bassin versant d'Itacaiúnas (BVI). les données historiques de la station de Marabá, dans l'est de l'Amazone, ont été utilisée comme données de contrôle. Les données interpolées et observées ont été validées avec les données de contrôle. La technique du quantile a été utilisée pour identifier les seuils annuels d'intensité des précipitations et les périodes saisonnières. Une comparaison a été effectuée avec les données sur les précipitations et la température de l'air pour déterminer les effets des événements ENSO entre 1980 et 2016. Nos résultats ont montré que la station Onça Puma était la plus pluvieuse parmi les sous-zones étudiées, par rapport a la variabilité annuelle. Le mois de mars a été le mois le plus pluvieux et le mois de juillet le moins pluvieux pour le bassin versant. L'influence des événements ENSO sur la température de I'air a eu lieu dans les premières années, de 1980 à 2003, et les événements les plus importants ont eu une grande influence sur les précipitations dans la zone BVI. El Niño 2015/16 pourrait avoir eu un effet plus prononcé sur le comportement des précipitations 
dans les stations Fazenda Abadia et Sossego. Dans la station de Salobo (zone forestière), les courbes de précipitation associées à la survenue des événements ENSO ont été retardées, ce qui peut être lié à des variations temporelles de la dynamique des interactions sol-végétation-atmosphère.

MOTS-CLÉS: précipitation, température, climatologie, El Niño, La Niña

\section{INTRODUCTION}

Anthropogenic actions, especially when associated with changes in vegetation cover and land use, have been considered to be the main causes of climate change in the Amazon region. Bonini et al. (2014), when analyzing rainfall variations in the municipality of Colíder (Mato Grosso state-MT) in the southern Amazon, showed that the expansion of deforested areas decreases the precipitation rate and consequently that gradual reductions in rainfall can influence the hydrological cycle in tropical regions. Souza-Filho et al. (2016) obtained evidence that the conversion of forest cover to pasture was accompanied by changes in the hydro-climatological cycle in the Itacaiúnas River watershed (Pará state-PA) in the eastern Amazon, leading to a drier environment due to an increase in air temperature in the region, a decrease in relative humidity and an increase in river discharge.

For future assessments regarding the causes and consequences of these actions with regard to the environment, continuous weather and climate monitoring is of fundamental interest to the general society. Meteorological data have multiple applications of a broad social interest, extending from the productive sector, with interests in the fields of wind and solar energy, agriculture, fishing and mining, to the public sector, which addresses the mitigation of damages caused by severe droughts, flooding in rural or urban areas, landslides, etc. The relevance of weather and climate data and products has led to the creation of international programs to obtain a complete record of meteorological variables around the globe to meet the demands mentioned above (LOPES et al., 2013).

Precipitation is considered to be a key variable for determining the climate in tropical regions. It is one of the most important input variables in the water balance of a river watershed (CAMARGO, 1971) and it is also essential in the planning of human activities and local development (DE SOUZA et al., 2009; AMANAJÁS and BRAGA, 2012; DE SOUZA et al., 2017). Ferreira et al. (2013) investigated the hourly variability in rainfall in three municipalities of the eastern Amazon during the rainy season, they have concluded that the rainfall regimes differed among the sites evaluated. According to the authors, the observed differences are due to the different weather systems that operate in each region, making the results relevant for monitoring in several important sectors such as Civil Defense, agriculture and mining. Marengo and Nobre (2009) stated that rainfall, river flow and air temperature are climate elements that are vital to the earth's environment, and analyses of the behavior of these parameters raise questions about climate change and its impacts on a region.

The atmospheric temperature is another parameter that has great influence in the main mechanisms of energy exchange and in the soilatmosphere interaction processes and it is therefore essential in micrometeorological and environmental studies (SANTOS et al., 2011). In tropical regions, the air temperature presents small variations throughout the year relative to most climate variables (LOPES et al., 2013). It is an integral 
part of any system involving atmospheric processes, since changes in the behavior of the atmosphere that are caused by differences in surface heating are mainly expressed in terms of variations in the mean temperature, which is also a parameter that is sensitive to changes in land use and land cover (COHEN et al., 2007; CORREIA et al., 2007, 2008).

Other factors that have an effect on precipitation and mean air temperature are the meso- and large-scale weather systems, since they contribute to the weather and climate variations in the Amazon region. Such weather systems include the Intertropical Convergence Zone (ITCZ) (HASTENRATH, 1991; REBOITA et al., 2010; FERREIRA et al., 2015), the South Atlantic Convergence Zone (SACZ) (CARVALHO et al., 2004; LOPES et al., 2013; QUADRO et al., 2016), and the El Niño-Southern Oscillation (ENSO) (GRIMM, 2011; LI et al., 2011; ANDREOLI et al., 2016; PEREIRA et al., 2017). ENSO, an ocean-atmosphere coupling phenomenon, is a major cause of climate variability, affecting global atmospheric circulation, and it has a significant influence on precipitation and air temperature variation throughout the planet. It consists of an oceanic component, El Niño (EN) or La Niña (LN), and an atmospheric component, the Southern Oscillation (PEREIRA et al., 2017). EN corresponds to the positive anomaly of the central and eastern tropical Pacific Ocean sea surface temperature (SST), and LN refers to the reverse process, e.g., a negative SST anomaly (PHILANDER et al., 1989). ENSO is an important source of interannual climate variability in South America, and together with the tropical Atlantic Ocean, it modulates a large part of the interannual climate variance over the Amazon (MARENGO and NOBRE, 2009; LI et al., 2011; ANDREOLI et al., 2012; CHIODI and HARRISON, 2016). In the present study, the term ENSO refers to EN/LN events.

In this context, the present study aims i) to characterize the climatic behavior of rainfall and air temperature in four distinct subareas, one in a forest area, one in a pasture area and two in (forest-pasture) transition areas in the Itacaiúnas River Watershed (IRW); and ii) to identify the possible effects of ENSO events on these climate variables in the four subareas from January 2015 to December 2016.

\section{MATERIALS AND METHODS}

\subsection{CHARACTERIZATION OF THE STUDY AREA}

The IRW is located between the latitudes $05^{\circ} 10^{\prime}$ and $07^{\circ} 15^{\prime}$ South and longitudes $48^{\circ} 37^{\prime}$ and $51^{\circ} 25^{\prime}$ West, in the Tocantins-Araguaia hydrographic region in the eastern Amazon (BRAZIL, 2003). The IRW drains an area of approximately $42,000 \mathrm{~km}^{2}$ and is located approximately $600 \mathrm{~km}$ south of the Equator (Figure 1). In terms of landscape, the Serra dos Carajás stands out with an altitude ranging from 400 to $900 \mathrm{~m}$, in contrast to adjacent areas with altitudes that range from 80 to $300 \mathrm{~m}$. In the watershed area, there are two primitive types of soil cover: tropical forest and montane savanna. However, land use is dominated by extensive pastures that surround a mosaic of forest remnants. The IRW area includes indigenous lands and conservation areas that are protected by law, occupying $11,700 \mathrm{~km}^{2}$, or roughly a quarter of the watershed area (SOUZA-FILHO et al., 2016; SILVA JÚNIOR et al., 2017a, b). 


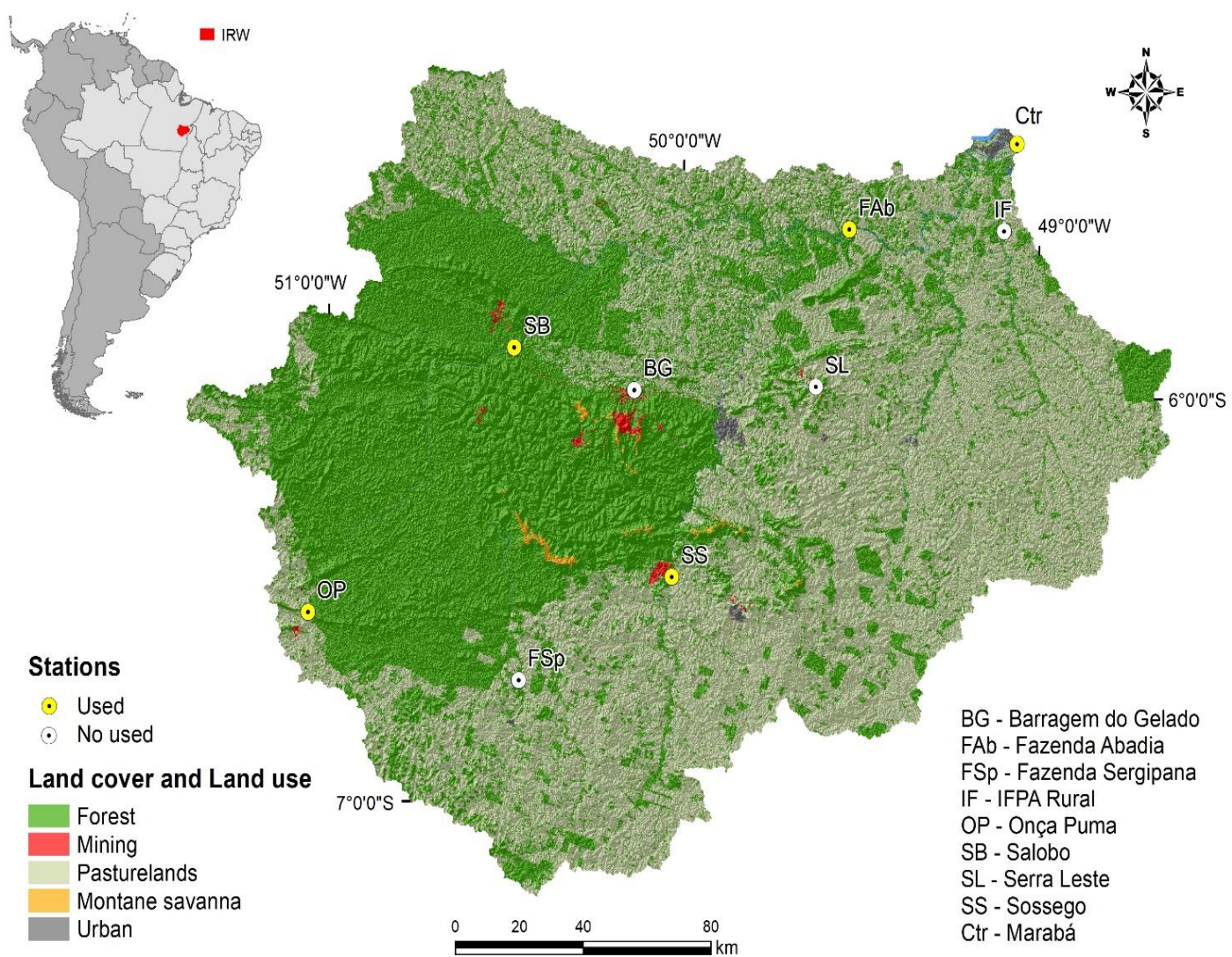

Figure 1 - Map of the Itacaiúnas River Watershed (IRW). The yellow dots represent the location of the weather stations studied: Salobo (SB), Fazenda Abadia (FAb), Onça Puma (OP) and Sossego (SS), and the INMET Marabá control station (Ctr).

The climate in the region is a monsoon climate $(\mathrm{Am})$, which is a tropical rainy climate (hot and humid) with a mean air temperature above $26^{\circ} \mathrm{C}$ (INMET, 1992; ALVARES et al., 2013). Because the region is located in the equatorial zone, there is a higher solar incidence on the surface, where solar energy is converted to sensible heat flow (heating) and latent heat flux (evapotranspiration), contributing directly to the convection process and, later, to precipitation (SODRE et al., 2015). The seasonal mean temperature range in the state of Pará does not vary significantly, with variations on the order of 1 to $2{ }^{\circ} \mathrm{C}$. Specifically in the IRW region, the mean value recorded is $27.2^{\circ} \mathrm{C}$, with a minimum annual temperature of $26.6^{\circ} \mathrm{C}$ in January and a maximum annual temperature of $28.1^{\circ} \mathrm{C}$ in September.

The rainfall regime is characterized by two well-defined seasons, one rainy, regionally known as Amazonian winter, and another dry, which is called Amazonian summer (LOPES et al., 2013). The rainy (November to May) and dry (June to October) seasons are well defined, in which total annual rainfall can vary from $1,800 \mathrm{~mm}$ to $2,300 \mathrm{~mm}$ during the rainy season and from $10 \mathrm{~mm}$ to $350 \mathrm{~mm}$ during the dry season (MORAES et al., 2005; SILVA JÚNIOR et al., 2017a). The main weather system that affects the rainfall regime during the rainy season in southeastern Pará, in the IRW region, is the band of convective 
clouds of the Intertropical Convergence Zone (ITCZ). In the dry season, the rainfall regime is influenced by frontal systems, which are responsible for the convective activity over the eastern Amazon (DE SOUZA et al., 2017).

\subsection{DATA ACQUISITION}

The comparative analysis between the mean seasonality and the observed data, as well as their respective interannual variabilities, was made using:

a) Historical data series for the four weather stations installed by the Vale Institute of Technology (ITV), namely: Salobo (SB), Fazenda Abadia (FAb), Onça Puma (OP) and Sossego (SS). These series were obtained for the points where the four ITV stations are installed, from the set of data interpolated in grid points:

- For precipitation: from a study carried out by Xavier et al. (2017), from January 1980 to December 2015 (36 years);

- For mean air temperature: from a study performed by Xavier et al. (2015), from January 1980 to December 2013 (34 years);

b) Historical series of observed data from 1980-2016 of the Marabá - PA station, belonging to Brazilian National Institute of Meteorology (INMET), defined in this study as the control station (Ctr).

In addition to the data mentioned above, data from four ITV weather stations installed at IRW, cited above (Figure 1), were collected and used for the period of 2015 to 2016 . These stations are located in sites with distinct land use and vegetation cover, as shown in Table 1 . Data from the weather stations were collected and transmitted to the ANA (National Water Agency) database platform and were stored on the Hidro Web platform (Hydrological Information System). The variables recorded and transmitted at regular intervals of one hour included precipitation $(\mathrm{mm})$, minimum and minimum air temperature $\left({ }^{\circ} \mathrm{C}\right)$, minimum and maximum air relative humidity $(\%)$, wind direction $\left({ }^{\circ}\right)$, minimum and maximum wind velocity $(\mathrm{m} / \mathrm{s})$, mean and maximum solar radiation $(\mathrm{W} / \mathrm{m} 2)$, and minimum and maximum water level $(\mathrm{mm})$.

Table 1 - Weather stations with their respective locations and characteristics.

\begin{tabular}{|c|c|c|c|c|}
\hline Station & $\begin{array}{l}\text { Geographic } \\
\text { location }\end{array}$ & $\begin{array}{c}\text { Altitude } \\
\text { (m) }\end{array}$ & Municipality & Environment \\
\hline Salobo (SB) & $\begin{array}{l}05^{\circ} 52^{\prime} 17^{\prime \prime} \mathrm{S} \\
50^{\circ} 28^{\prime} 44^{\prime \prime} \mathrm{W}\end{array}$ & 178 & Marabá-PA & Forest \\
\hline $\begin{array}{l}\text { Fazenda Abadia } \\
\text { (FAb) }\end{array}$ & $\begin{array}{l}05^{\circ} 34^{\prime} 39^{\prime \prime} \mathrm{S} \\
49^{\circ} 32^{\prime} 05^{\prime \prime} \mathrm{W}\end{array}$ & 134 & Marabá-PA & Pasture \\
\hline $\begin{array}{l}\text { Onça Puma } \\
\text { (OP) }\end{array}$ & $\begin{array}{l}06^{\circ} 31^{\prime} 46^{\prime \prime} \mathrm{S} \\
51^{\circ} 03^{\prime} 33^{\prime \prime} \mathrm{W}\end{array}$ & 259 & $\begin{array}{l}\text { Ourilandia do } \\
\text { Norte-PA }\end{array}$ & $\begin{array}{l}\text { Forest/pasture } \\
\text { transition }\end{array}$ \\
\hline Sossego (SS) & $\begin{array}{l}06^{\circ} 26^{\prime} 35^{\prime \prime S} \\
50^{\circ} 02^{\prime} 05^{\prime \prime} \mathrm{W}\end{array}$ & 236 & $\begin{array}{l}\text { Canaã dos } \\
\text { Carajás-PA }\end{array}$ & $\begin{array}{l}\text { Forest/pasture } \\
\text { transition }\end{array}$ \\
\hline
\end{tabular}


The Salobo (SB) station is located within the National Forest of TapirapéAquiri (FLONATA), a conservation unit created in 1989 (Decree 97720 from 05.05.1989). The Fazenda Abadia station (FAb) is located in a pasture area, approximately $55 \mathrm{~km}$ from the mouth of the watershed. The Onça Puma (OP) and Sossego (SS) stations are located in a forest-pasture transition area. Based on a study by Alvares et al. (2013) for Brazil, whose methodology is based on the latest version of the climatic classification of Koppen (1936), it is verified that there is no differentiation in the type of climate between the four sub-areas (stations) of the IRW, especially regarding the criteria of temperature and precipitation, defined as type Am (monsoon). However, the northeastern portion of the basin, where FAb and Marabá (Ctr) stations are installed, is located in the range where the characteristics are of Aw climate (tropical with dry winter and rainy season of summer).

For IRW stations, daily and monthly air temperature (Tmean) and cumulative precipitation were calculated for the period from January 2015 to December 2016. This period was selected due to the need to evaluate the possible influence of the EN and LN events that occurred during those years on the local climate variables, using as a comparison the climatological mean of these variables for the region. To compare the precipitation and the mean temperature climatology with EN and LN events, Oceanic Niño Index (ONI) values from 1980 to 2016 were acquired as one of the main indices for monitoring these events. This index is calculated from the Sea surface temperature (SST) anomalies in an east-central equatorial Pacific Ocean area called the Niño region -3.4 ( $5 \mathrm{~S}$ to $5 \mathrm{~N}, 170 \mathrm{~W}$ to $120 \mathrm{~W}$ ). The ENSO phenomenon occurs when ONI values exceed the mean by $0.5^{\circ} \mathrm{C}$ (EN) or $-0.5^{\circ} \mathrm{C}(\mathrm{LN})$, for a period of more than three months. This index can be obtained from the National Oceanic and Atmospheric Administration (NOAA, 2017), available at www.cpc.ncep.noaa.gov. The intensity of EN/LN events was obtained from http://ggweather.com/enso/oni.htm.

\subsection{STATISTICAL ANALYSIS}

In this study, the quantile statistical technique was used, by Pinkayan (1966); this technique has been widely used by Xavier and Xavier (1999), Xavier (2001), Xavier et al. (2002, 2007) in several studies. The quantile technique is based on the distribution of the cumulative frequency, where the greater the number of observations available, the better the approximation of the probability density function that describes the phenomena. In summary, the methodology proposed by Xavier and Xavier (1987) states that given a variable $\mathbf{X}$ that represents the cumulative values of precipitation in a certain subinterval of the year (month, bimester, quarter, semester, or even a whole year), $\mathbf{Q}_{\mathbf{p}}$ is defined as the limit of the quantile range for the variable $\mathbf{X}$, where $\mathbf{p}$ is the probability of occurrence, such that $\mathbf{X}$ is smaller than $\mathbf{Q}_{\mathbf{p}}$. Therefore, the choice of the quantile range must satisfy the following relation: Prob $\left(\mathbf{X} \leq \mathbf{Q}_{\mathbf{p}}\right) \mathbf{=} \mathbf{p}$. The quantiles used refer to the values for $\mathbf{p}: 0.15 ; 0.35 ; 0.65$ and 0.85 , corresponding to five categories. The ranges for each percentile (Table 2) represent probabilities or expected frequencies for each of the events that may occur along the time series of variable $\mathbf{X}$. 
Table 2 - Classes or categories of precipitation using the quantile technique.

\begin{tabular}{lll}
\hline \multicolumn{1}{c}{ Classes } & \multicolumn{1}{c}{ Thresholds } & \multicolumn{1}{c}{ Quantile range } \\
\hline Very dry $(\mathrm{VD})$ & $\mathrm{X}_{\mathrm{i}} \leq \mathrm{Q}_{0.15}$ & $\mathrm{P}_{\mathrm{i}} \leq 0.15$ \\
Dry $(\mathrm{D})$ & $\mathrm{Q}_{0.15}<\mathrm{X}_{\mathrm{i}} \leq \mathrm{Q}_{0.35}$ & $0.15<\mathrm{P}_{\mathrm{i}} \leq 0.35$ \\
Normal $(\mathrm{N})$ & $\mathrm{Q}_{0.35}<\mathrm{X}_{\mathrm{i}}<\mathrm{Q}_{0.65}$ & $0.35<\mathrm{P}_{\mathrm{i}}<0.65$ \\
Rainy $(\mathrm{R})$ & $\mathrm{Q}_{0.65} \leq \mathrm{X}_{\mathrm{i}}<\mathrm{Q}_{0.85}$ & $0.65 \leq \mathrm{P}_{\mathrm{i}}<0.85$ \\
Very rainy $(\mathrm{VR})$ & $\mathrm{X}_{\mathrm{i}} \geq \mathrm{Q}_{0.85}$ & $\mathrm{P}_{\mathrm{i}} \geq 0.85$ \\
\hline
\end{tabular}

Source: Xavier and Xavier (1999).

The climatological normals of the historical series, acquired from Xavier et al. (2017), were also calculated for the four stations (ITV) under study, as were the precipitation values corresponding to the percentiles, which were used as thresholds of the ranges corresponding to the events shown in Table 2. The objective of using this technique was to identify the characteristic months of each seasonal period and the interannual variability over the period from 1980 to 2015.

\section{RESULTS AND DISCUSSION}

Figure 2 presents the interannual variability in precipitation for the four weather stations under study, using data interpolated by Xavier et al. (2017), for the period from 1980 to 2015. The year 1985 was the highest rainfall year for all stations and can therefore be classified as a very rainy (VR) year, with the station SB (Figure 2a) standing out with a cumulative value of $2,948.4 \mathrm{~mm}$ (Table 2). This behavior may be associated with the LN event that occurred in that year. On the other hand, the year 2015, for all stations, was the driest in the historical series. In particular, the SB station presented the lowest annual total rainfall $(1,207.6 \mathrm{~mm})$, possibly as a result of the 2015/16 EN event, which is considered to be one of the most intense EN events recorded, and is therefore classified as of very strong intensity. 


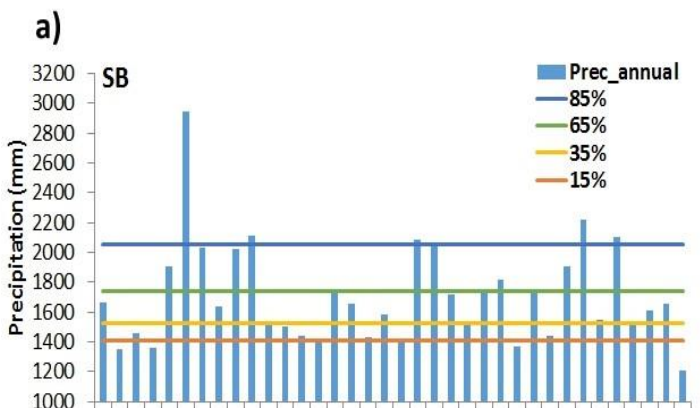

b)
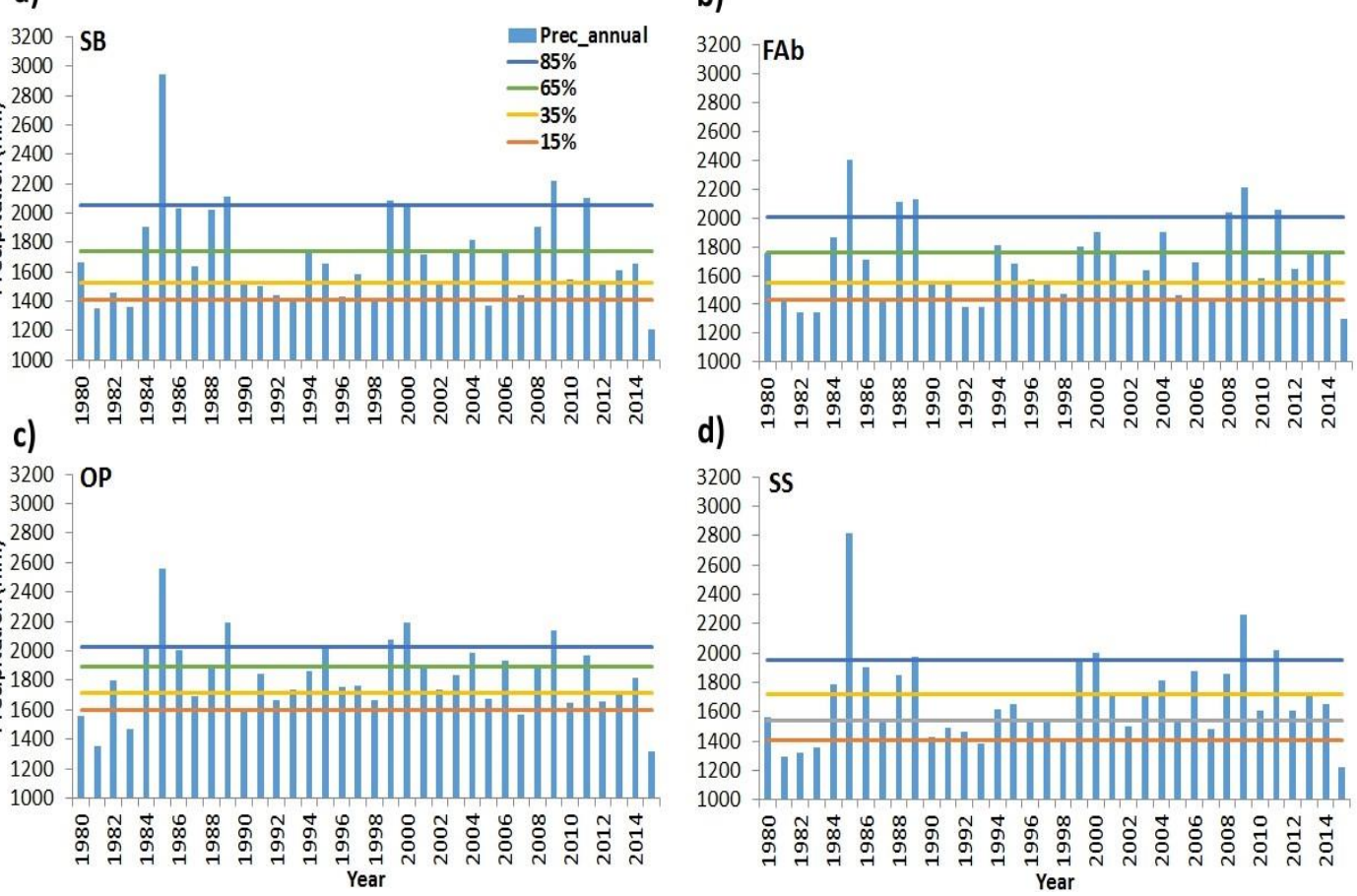

Figure 2 - Interannual variability in precipitation for the 1980-2015 period in the stations a) Salobo-SB, b) Fazenda Abadia-FAb, c) Onça Puma-OP and d) Sossego-SS.

The annual precipitation pattern of the Onça Puma (OP) station (Figure 2c) presented annual totals that were markedly higher than those of other stations, despite being located at almost the same latitude and altitude as the Sossego (SS) station and characterized by the same type of land use (forest/pasture transition). This situation is evident in the $85 \%, 65 \%, 35 \%$ and $15 \%$ percentiles of the OP station, which show higher values than the other stations, with the exception of the $85 \%$ threshold of the SB station, which presented a higher value $(2,050.1 \mathrm{~mm})$. The year 1991 also stands out as another of the driest years of the historical series in all stations, particularly the SS station, which recorded the lowest cumulative annual precipitation $(1,294.9$ $\mathrm{mm}$ ), a finding that may be associated with the 1991/92 EN event, defined as being strong intensity.

Figure 3 shows the results obtained by calculating percentiles (15\%, $35 \%, 65 \%$ and $85 \%$ ) for the monthly climatology of the four stations studied, which was done to determine the months that best represent the seasonality of these stations. In accordance with Table 3, we considered that the very rainy period corresponds to the months exceeding the $85 \%$ percentile, the rainy period is between the $65 \%$ and $85 \%$ percentiles, dry months would be those with values $<15 \%$, and transition months would be those with values between the $35 \%$ and $65 \%$ percentiles. The methodology used for establishing the thresholds was adopted from Carmo et al. (2015), but in this study, the thresholds were modified and adapted according to the trends observed for the IRW. 
a)

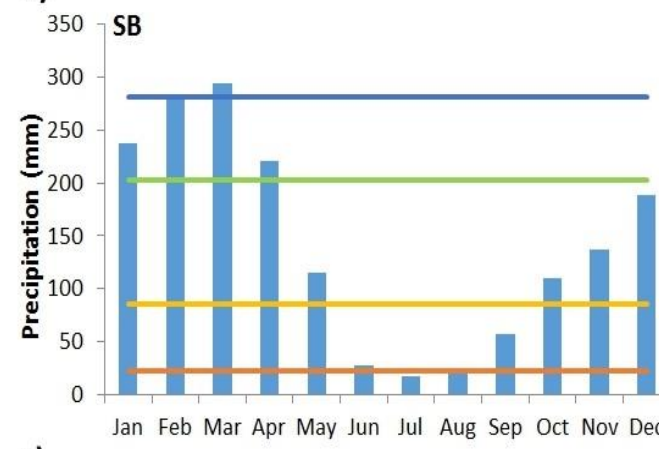

c)

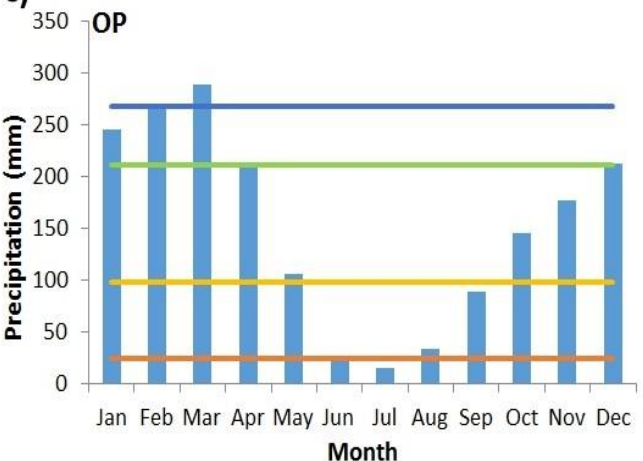

b)

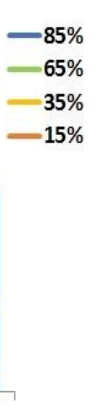

d)

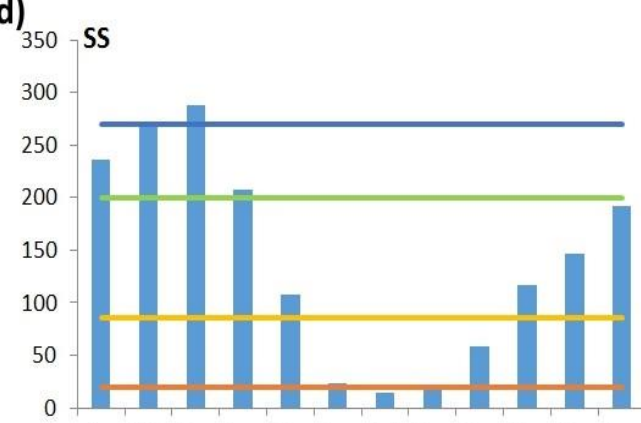

Jan Feb Mar Apr May Jun Jul Aug Sep Oct Nov Dec Month

Figure 3 - Climatology of the total monthly precipitation and percentiles used to determine the months representative of the seasonal periods of the stations a) SaloboSB, b) Fazenda Abadia-FAb, c) Onça Puma-OP and d) Sossego-SS.

Table 3 - Classification of the seasonal periods using the percentile technique.

\section{Thresholds}

\begin{tabular}{ll}
\hline Prec $(\mathrm{i}) \leq \operatorname{Prec}(15 \%)$ & Dry \\
Prec $(35 \%)<\operatorname{Prec}(\mathrm{i}) \leq \operatorname{Prec}(65 \%)$ & Dry-rainy transition \\
& Rainy-dry transition \\
$\operatorname{Prec}(65 \%)<\operatorname{Prec}(\mathrm{i}) \leq \operatorname{Prec}(85 \%)$ & Rainy \\
$\operatorname{Prec}(\mathrm{i})>\operatorname{Prec}(85 \%)$ & Very Rainy \\
\hline $\begin{array}{l}\text { *Prec: Precipitation; } \mathrm{i}=1,2, \ldots \mathrm{N} \text { (years). Source: Modified from Carmo et al. } \\
(2015) .\end{array}$
\end{tabular}

The rainiest period was the four months from January to April, with the month of March being the rainiest with a threshold exceeding $85 \%$, which agrees with the literature for the Amazon region (MORAES et al., 2005; SILVA JÚNIOR et al., 2017a). Conversely, the month of July was the driest, with the exception of the FAb station (Figure $3 b$ ), for which the month of August was the month with a value below the $15 \%$ percentile threshold $(17.5 \mathrm{~mm}), 15.3 \mathrm{~mm}$. May was identified as the rainy-dry transition month according to the percentile classification, whereas the month of November characterizes the dry-rainy 
transition period for the ITV stations, as also defined by Silva Júnior et al. (2017a).

In Figure 4, the climatological fluctuations of the air temperature in the ITV stations (Clim - interpolated) and control station (Maraba) show higher values than those observed for the years 2015 and 2016 at the four stations. In this figure, the mean temperatures for the months of June and July recorded in 2015 and 2016 stand out. Although the climatological records (Clim and Ctr) show lower values in these months, their curves are smoother when compared to the four ITV stations. The more pronounced slopes in these months (June and July) can be explained by the maximum temperature anomalies identified by the Center for Weather Forecasting and Climate Studies at the Brazilian National Institute for Space Research (CPTEC/INPE), which present negative maximum temperature anomalies (between -2 and $-3^{\circ} \mathrm{C}$ ) during these months in the IRW region (Figure 5 ). The minimum temperature anomalies remained practically neutral during these periods, thus reflecting low mean temperatures in the region.

a)

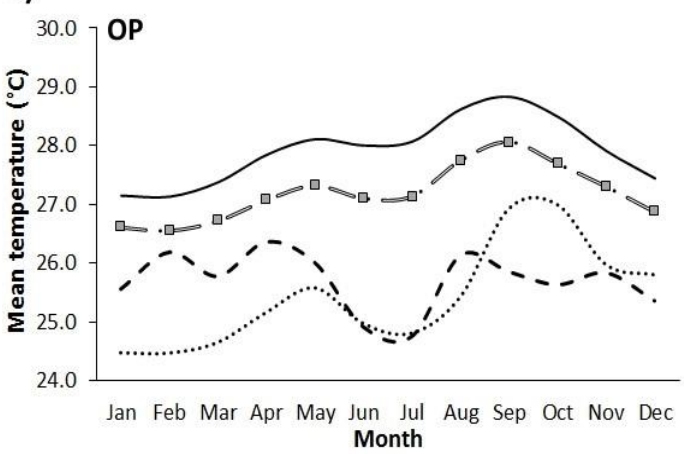

b)
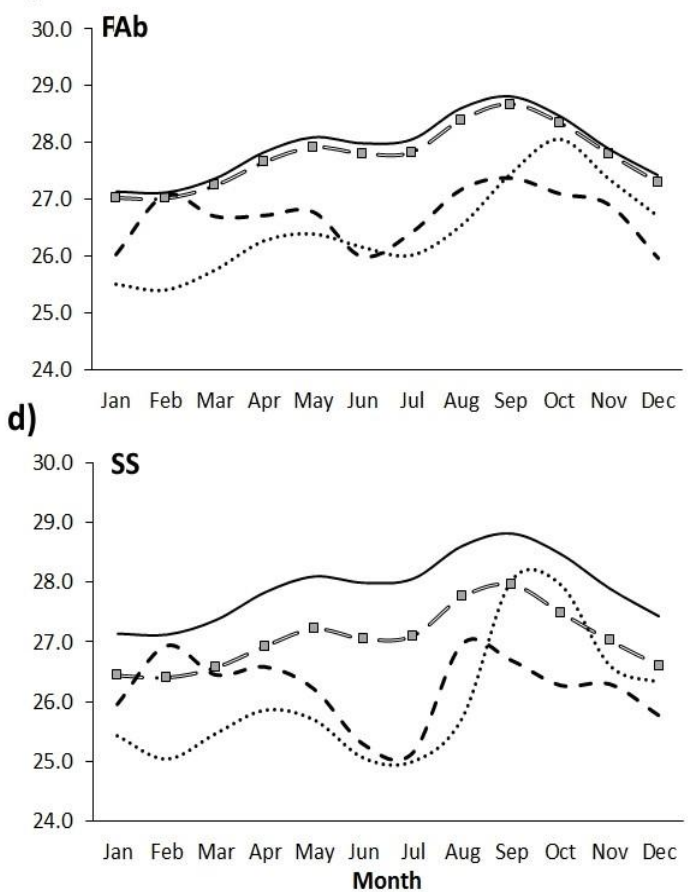

Figure 4 - Comparison between estimated monthly climatological means (1980-2013)Clim, observed (2015 and 2016) of the air temperature of the stations: a) Salobo-SB, b) Fazenda Abadia-FAb, c) Onça Puma-OP and d) Sossego-SS, and the climatological mean of the Marabá-Ctr control station. 

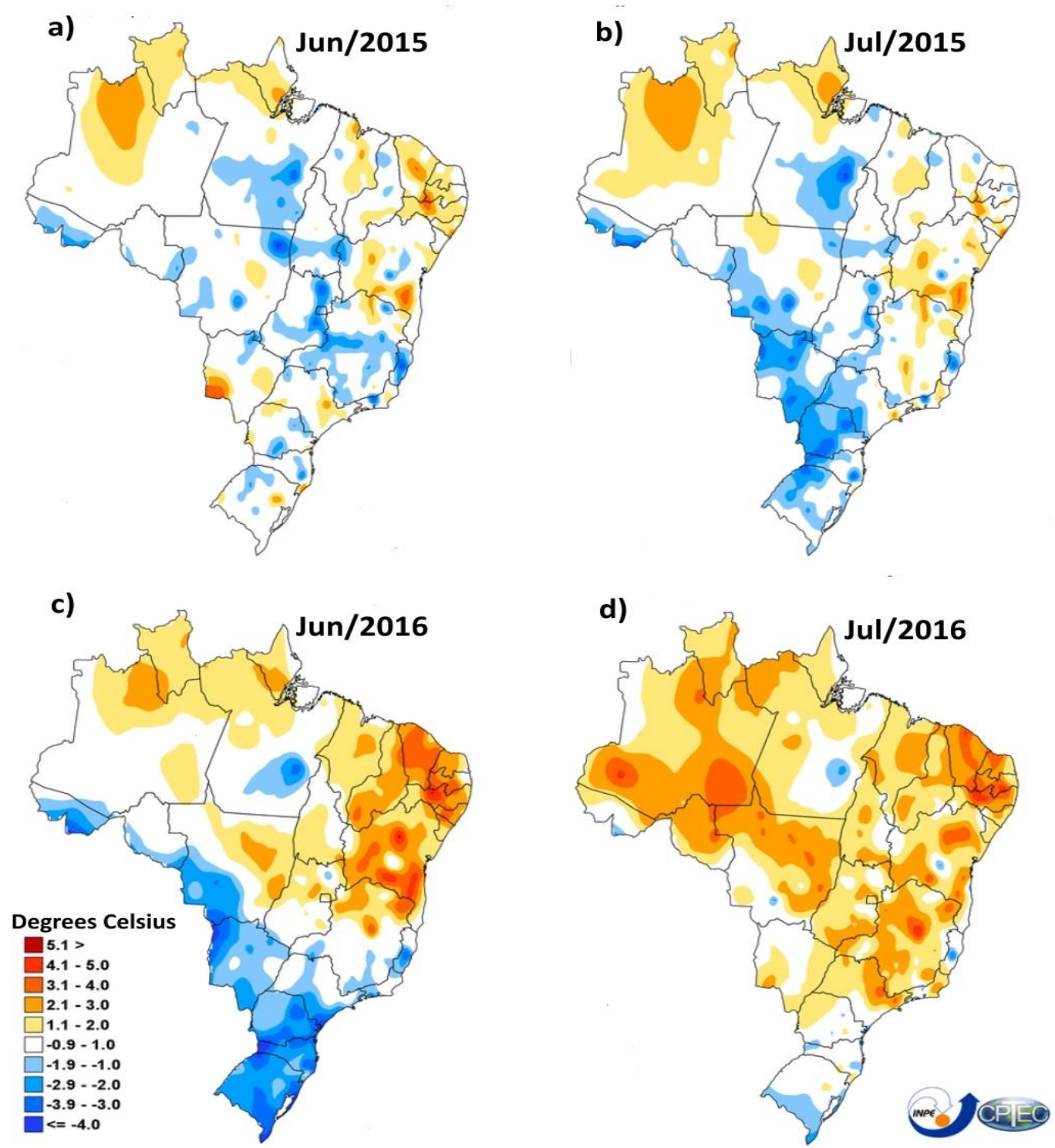

Figure 5 - Maximum temperature anomaly maps $\left({ }^{\circ} \mathrm{C}\right)$ for all of Brazil for the months: a) June/2015, b) July/2015, c) June/2016 and d) July/2016. Source: CPTEC/INPE.

The FAb station (Figure 4b) shows a mean climatological data curve that is similar to the Marabá station, suggesting an excellent correlation between the interpolated data and the historical data observed for the Marabá station. Therefore, the other stations have the same sinuosity, but the amplitudes between the maximum and minimum values are smaller. The monthly means of the observed air temperature values show greater variations throughout the year, especially during the year 2015 and in particular for the SS station (Figure $4 \mathrm{~d})$, whose oscillation is higher, around $3^{\circ} \mathrm{C}$. The minimum air temperature $\left(25.0^{\circ} \mathrm{C}\right)$ was recorded in February and the maximum $\left(28.0^{\circ} \mathrm{C}\right)$ in October. For the year 2016, the curve for this variable is more similar to the historical 
behavior in the first months, especially at the SS station, which reaches $26.9^{\circ} \mathrm{C}$ in February, a value higher than the climatological mean.

Figure 6 shows monthly mean air temperature variations at the ITV stations (observed data) and at the control station (Marabá) for the years 2015 and 2016. There is a clear difference in the magnitude of the data observed in the ITV stations compared to the control data. This difference may be related to the type of land use, since the control station is located in the urban area of Marabá municipality. The urban characteristics (buildings, paved roads, industrial areas, etc.) seem to be the causal factor of this difference in air temperature. In fact, vegetation removal promotes the reduction of the evapotranspiration process and, consequently, there is a minimum cooling by evaporation in the city (PINHO, 2000). Studies have reported that the reduction of green areas and soil waterproofing, due to the urbanization process of the cities, contribute to the increase of air temperature (AMORIM et al., 2009; AMORIM, 2010; ROCHA et al., 2011). Callejas et al. (2011) verified that there was an increase of more than $2.13^{\circ} \mathrm{C}$ of surface temperatures in urbanization areas in the city of Várzea Grande (MT) between 1986 and 2007.

Therefore from a qualitative perspective, the stations are accurately recording the general characteristics and climate variabilities of the watershed area. Among the stations, the FAb station stands out as its fluctuations over time were the most similar to the control station, which is expected since they are located in the same municipality (Marabá), thus providing a qualitative validation of the data from ITV stations.

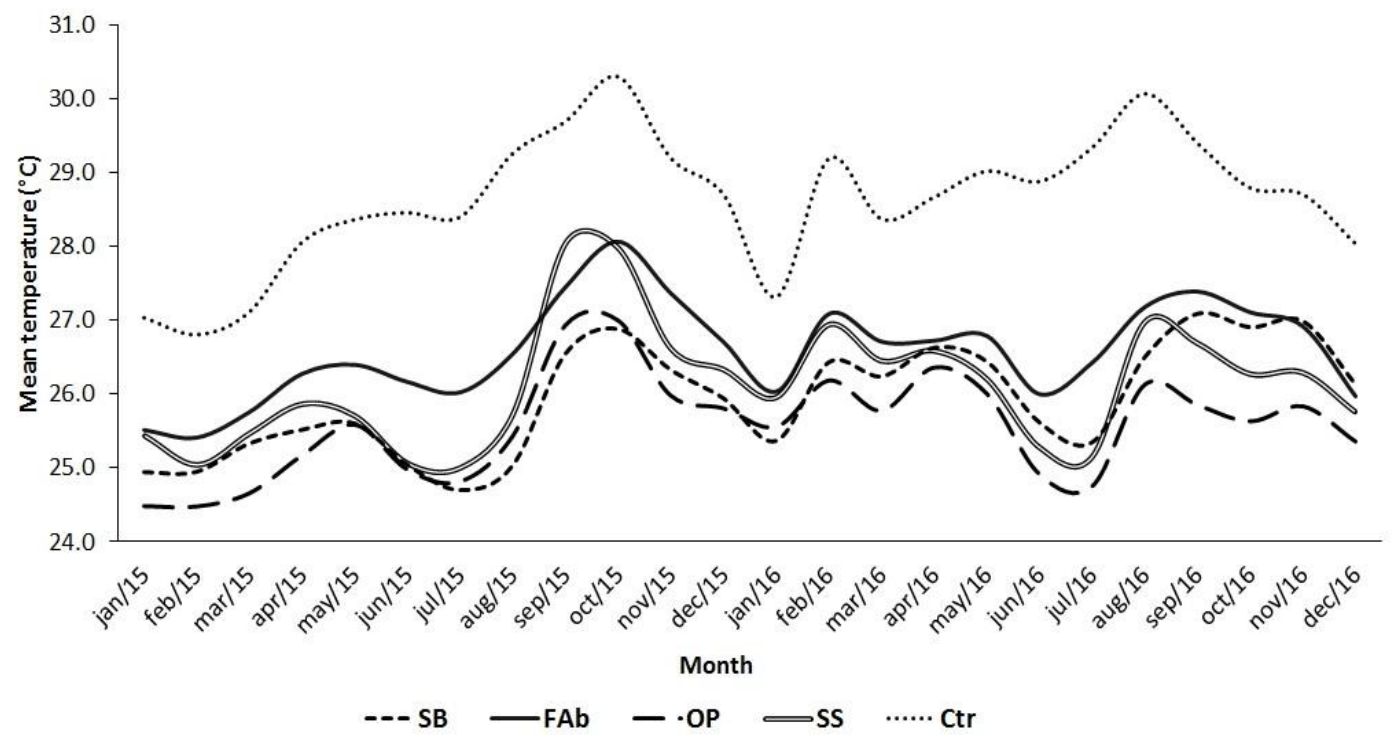

Figure 6 - Monthly mean air temperature variation during the years 2015 and 2016 in the control station (Marabá)-Ctr and the stations Salobo-SB, Fazenda Abadia-FAb, Onça Puma-OP and Sossego-SS.

Figure 7 compares the climatological means of interpolated and observed precipitation data (2015 and 2016) at the ITV stations with the occurrences of 
EN and LN events in the period 1980-2016. In general, the precipitation behaviors match the occurrence of EN events, resulting in rainfall deficits, and LN events that are characterized by above-average precipitation, which is corroborated by the literature for the Amazon region (DE SOUZA et al., 2005; ANDREOLI et al., 2012; CAVALCANTI et al., 2013; SOUSA et al., 2015). Regarding the 1982/83 EN event, which was classified as very strong, the year 1983 is characterized as a dry year for all stations (Figures 2 and 7). The estimates for the FAb (Figure 7b) and SS (Figure 7d) stations suggest a strong influence during the two years of the event, 1982 and 1983, with annual cumulative values of $1,347.5$ and $1,344.7 \mathrm{~mm}$ (FAb) and 1,323.0 and 1,359.8 $\mathrm{mm}$ (SS). This negative (estimated) precipitation anomaly was also evident for the four stations analyzed in the 1997/98 EN event that had very strong intensity, corroborating the study by Cavalcanti et al. (2013) on droughts in the Amazon.

a)

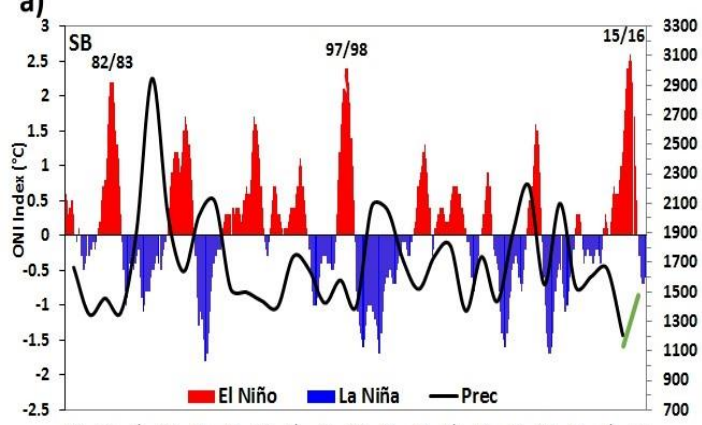

C)
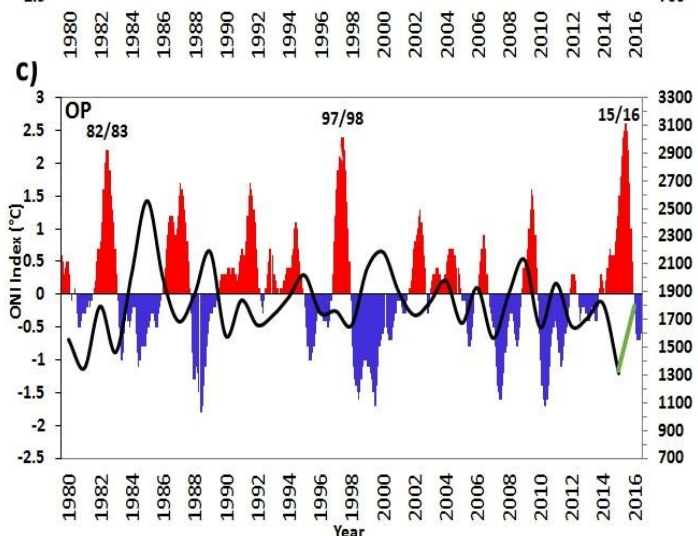

b)

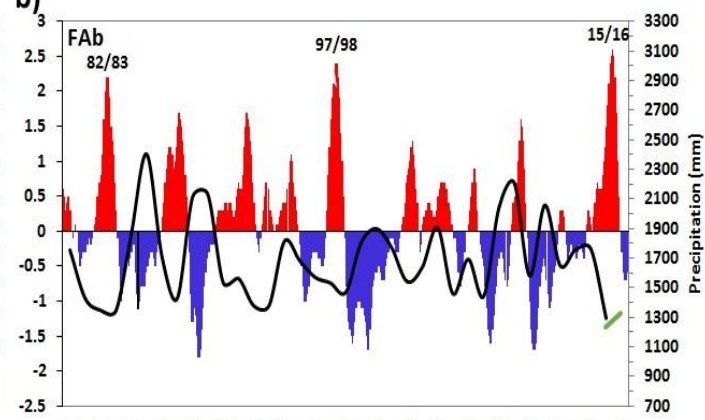
d)
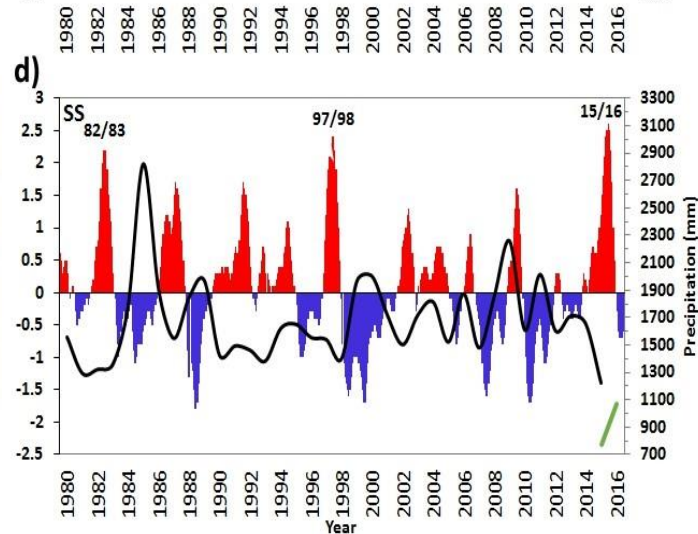

Figure $\mathbf{7}$ - Comparison between the climatological mean for precipitation data interpolated (black lines) and observed for 2015 and 2016 (green lines) at ITV stations: a) Salobo-SB, b) Fazenda Abadia-FAb, c) Onça Puma-OP and d) Sossego-SS, with the indices of occurrence of EN (columns in red) and LN (columns in blue) events, in the 1980-2016 period.

These results indicate a more marked influence of strong type EN events on precipitation in the IRW region, as shown in a study carried out by De Souza and Ambrizzi (2002) in the Amazon region. For the precipitation values observed in 2015 and 2016 (Figure 7 - green lines), this marked influence is associated with the 2015/16 EN event, which was identified as very strong. In 
particular, the SS station (Figure 7d) presented the lowest annual cumulative values for 2015 and 2016 (776.8 and 1,071.0 mm, respectively). At the SB station (Figure 7a), which is a forest area, there is a certain delay in the precipitation curves relative to the occurrence of ENOS, which may be associated with the effect of the vegetation cover and the greater relative time required for soil-vegetation-atmosphere interaction dynamics to occur. The vegetation contributes to this interaction mechanism through the interception of rainfall, as well as a mechanism of output of the most important water balance component, evapotranspiration. The OP station (Figure 7c) does not present such an evident response to these events.

Other evidence includes data for the year 1985, which was marked by a moderate LN event. In this year, all four stations had high annual cumulative precipitation, especially the SB station, located in a forest area (Figure 7a), and the SS station, located in a forest/pasture transition area (Figure 7d), reaching the highest positive precipitation anomalies of 2,948.4 and 2,819.3 mm, respectively. These results align with those of Sousa et al. (2015) from southeast Pará. In addition, this evidence is also shown in a historical report regarding the formation of the municipality of Ourilândia do Norte (OP station), which reports the remarkable winter of 1985, when the municipality was isolated due to the rainfall (CRUZ and PANAACHUK, 2014). In addition, the observed precipitation values for the ITV stations in the year 2015 were congruent with the interpolated values, in particular the OP station (Figure 7c), which registered a cumulative value of $1,331.2 \mathrm{~mm}$, the closest to the interpolated value $(1,314.7 \mathrm{~mm})$. On the other hand, the station SS (Figure $7 \mathrm{~d}$ ) showed a cumulative value of $776.8 \mathrm{~mm}$, well below the estimated amount for the year.

Figure 8 shows the climatological behavior of the mean air temperature in the four stations from Xavier et al. (2015) and observed data from these stations for the period of 2015 and 2016. The data are compared to the EN and LN events from the period 1980 to 2016. In the first years, it is evident that the occurrence of EN events is accompanied by the highest air temperature values, whereas negative peaks are observed during LN events. This is particularly evident in the 1982/83 EN (very strong), 1984/85 LN (weak) from 1986/87 EN (moderate), 1988/89 LN (strong), 1997/98 EN (very strong), 1998/01 LN (moderate), the longest of events (KAYANO et al., 2016), and 2002/03 EN (moderate), for the four ITV stations. However, since the 2002/03 EN event, the temperature in the stations does not follow the same pattern during the occurrence of the subsequent ENSOs, even for the years 2015 and 2016. The highest differences occur in the SB (Figure 8a) and SS (Figure 8d) stations, where the temperature during the $2009 / 10 \mathrm{EN}$ (moderate) reached $24.7^{\circ} \mathrm{C}$ in 2009, the lowest values of the historical series for these stations, which does not agree with the literature. 

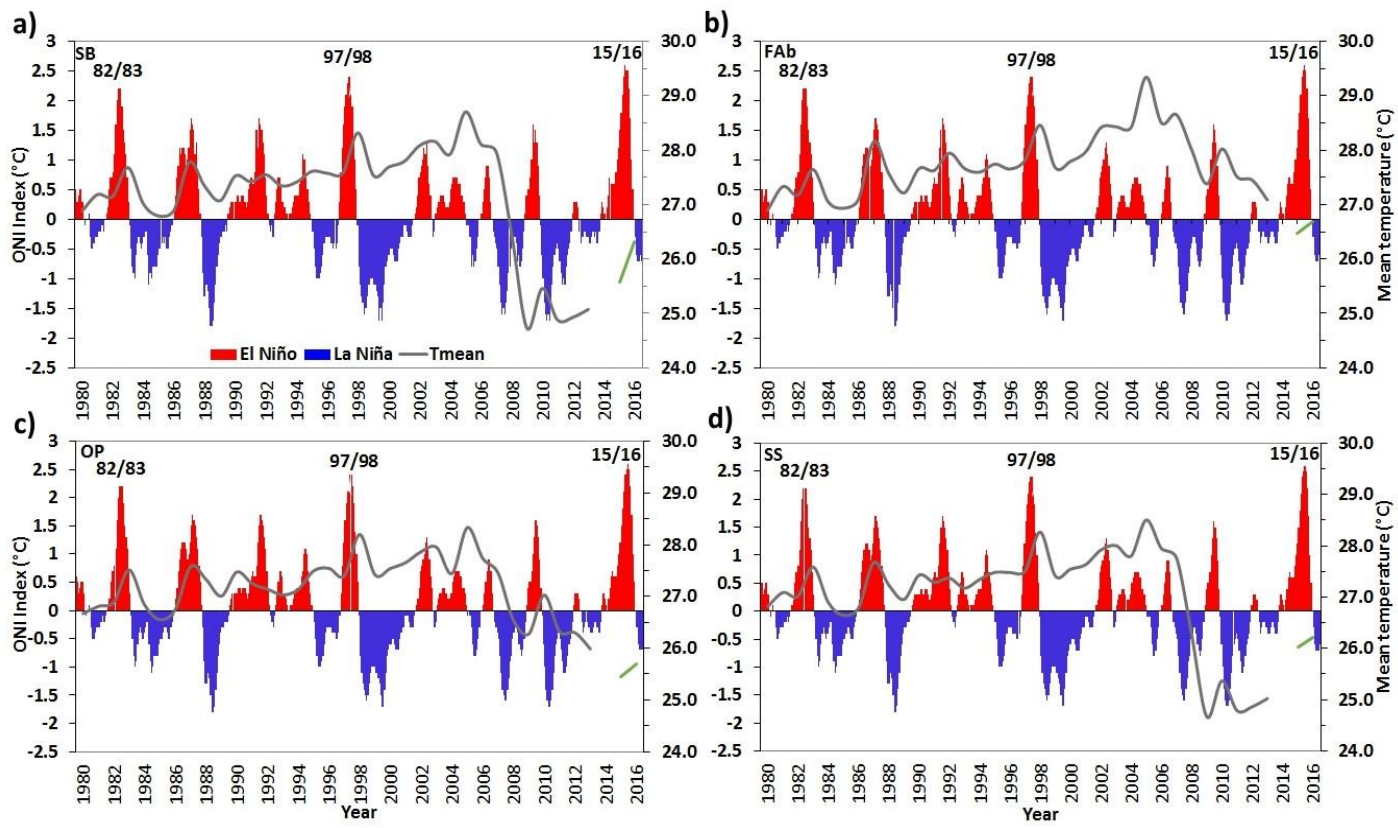

Figure 8 - Comparison between the climatological mean for air temperature data interpolated (gray lines) and observed for 2015 and 2016 (green lines) at ITV stations: a) Salobo-SB, b) Fazenda Abadia-FAb, c) Onça Puma-OP and d) Sossego-SS, with the indices of occurrence of EN (red columns) and LN (blue columns) events in the 19802016 period.

Figure 9 shows the monthly climatological mean precipitation (interpolated data-Clim) for the four stations, as well as for the Marabá station (observed data-Ctr), compared to the monthly cumulative rainfall observed for these stations in 2015 and 2016. In the SB station (Figure 9a), the monthly values presented variations compared to their climatology. In the months of February and March 2015, low values were recorded (26.6 and $101.0 \mathrm{~mm}$, respectively), and in turn, the months of July $(146.6 \mathrm{~mm})$ and November $(190.2$ $\mathrm{mm}$ ) registered values above the estimated historical mean for the station. The climatological mean data curve for the precipitation estimated by the FAb station (Figure 9b) was similar to the historical rainfall variability in the Marabá station (Ctr), which may represent a validation of the interpolated climatological data, since the FAb station is located in the municipality of Marabá-PA. 
a)

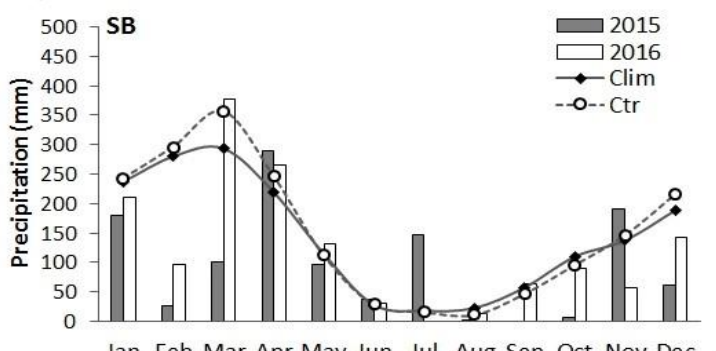

c)

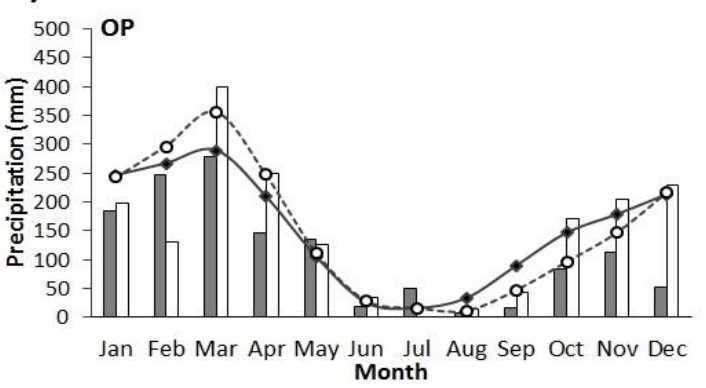

b)

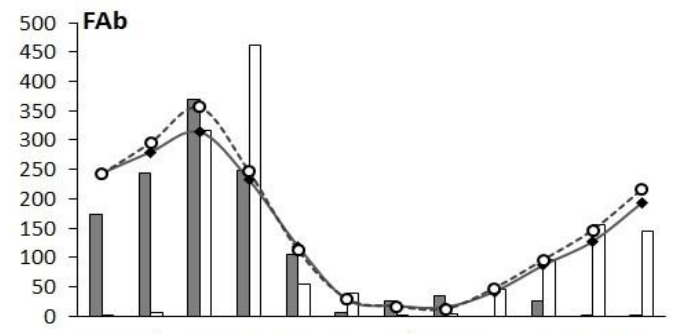

Jan Feb Mar Apr May Jun Jul Aug Sep Oct Nov Dec

d)

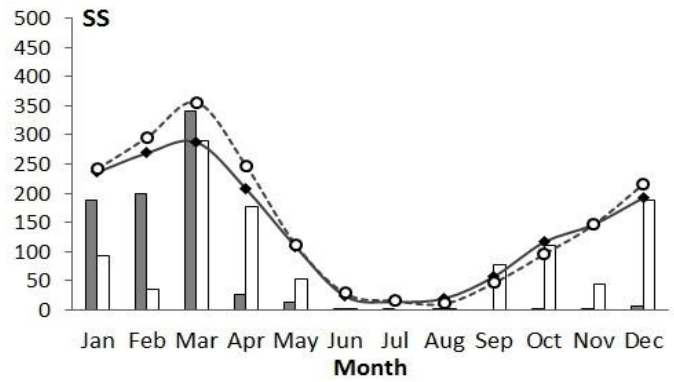

Figure 9 - Monthly cumulative precipitation for the stations a) Salobo-SB b) Fazenda Abadia-Fab c) Onça Puma-OP and d) Sossego-SS during the years 2015 (dark bars) and 2016 (white bars), climatological means for IRW (XAVIER et al., 2017)-Clim (blacklines) and Marabá-Ctr station (dashed lines) for the 1980-2016 period.

The year 2015 was marked by an EN event classified as MIX-type and very strong, whose influence resulted in negative precipitation anomalies in the Amazon, northeast and center-west of Brazil that were considered even more intense than the classic episodes EN of 1982/83 and 1997/98 (PEREIRA et al., 2017). The effect of this phenomenon may have more strongly influenced the rainfall behavior at the FAb station from June through February 2016 (Figure 9b), and in the SS station from April to February 2016 (Figure 9d), with negative precipitation anomalies in these periods compared to the estimated historical normal for each station.

In comparision to others, the OP station (Figure 9c) was less influenced by the 2015/16 EN event in terms of its cumulative precipitation values, although its effects are noticeable between August $(8.2 \mathrm{~mm})$ and December $(52.8 \mathrm{~mm})$ of 2015 when precipitation values were low compared to the climatological normal.

\section{CONCLUSIONS}

The analyses of the climatology of the ITV stations showed a good relationship with the records of the control station (Marabá), both for air temperature and for precipitation, thus validating the data collected for the IRW area. Likewise, there was similarity in the monthly air temperature fluctuations during the years 2015 and 2016 when comparing the observed data with the control data. The same was observed for the precipitation records, especially for the year 2015, which showed excellent agreement with the interpolated values, 
except for the SS station that recorded a cumulative value that was lower than the estimated value for this year. In summary, the records obtained at the ITV stations represent the general characteristics and climate variabilities of the watershed area, constituting a qualitative validation of these data.

Concerning the interannual variability for precipitation in the stations, we conclude that the OP station area was characterized as the rainiest, with annual precipitation higher than that of the other stations. Regarding seasonality, the month of March is the rainiest, and the month of July is the driest, supporting the literature for the region; an exception is the FAb station, where August was the driest.

For the ENSO events, since 1980, the estimated air temperature had higher values during EN events and lower values during LN events, which was more evident until the year of 2003 for the four ITV stations. However, from 2003 onward, the temperature in the stations did not follow the same pattern of occurrence of the subsequent ENSO events. It has also been found that there is a more evident influence of strong EN and LN events on precipitation in the IRW region. The 2015/16 EN event, classified as very strong, may have had a more marked effect on the rainfall behavior in the FAb and SS stations, and the OP station was the least influenced compared to its climatological normal. In addition, a delay in the precipitation curves with respect to the occurrence of ENSO events was observed at the SB station (forest area), which may be an effect of the vegetation cover and may also reflect temporal variations in soilvegetation-atmosphere interaction dynamics.

\section{ACKNOWLEDGMENTS}

The authors are grateful to the Vale Institute of Technology for Sustainable Development (ITV DS) for the financial and logistical support and to Brazilian National Council for Scientific and Technological Development (CNPq) for the Business Postdoctoral Fellowship (PDI) granted to the first author.

\section{REFERENCES}

ALVARES, C. A.; STAPE, J. L.; SENTELHAS, P. C.; GONÇALVES, J. L. M.; SPAROVEK, G. Köppen's climate classification map for Brazil. Meteorologische Zeitschrift, v. 22, n. 6, p. 711-728, 2013.

AMANAJÁS, J. C.; BRAGA, C. C. Padrões espaço-temporal pluviométricos na Amazônia Oriental utilizando análise multivariada. Revista Brasileira de Meteorologia, v. 27, n. 4, p. 423-434, 2012.

AMORIM M. C. C. T.; DUBREUIL V.; QUENOL H.; SANT'ANNA J. L. Características das ilhas de calor em cidades de porte médio: exemplos de Presidente Prudente (Brasil) e Rennes (França). Confins [Online], n. 7, p. 1-16, 2009.

AMORIM, M. C. C. T. Climatologia e gestão do espaço urbano. Mercator - Revista de Geografia da UFC, v.9, p.71 - 90, 2010.

ANDREOLI, R. V.; OLIVEIRA, S. S.; KAYANO, M. T.; VIEGAS, J.; DE SOUZA, R. A. F.; CANDIDO, L. A. The influence of different El Niño types on the South 
American rainfall. International Journal of Climatology, v. 37, n. 3, p. 13741390, 2016.

ANDREOLI, R. V.; SOUZA, R. A. F.; KAYANO, M. T.; CANDIDO, L. A. Seasonal anomalous rainfall in the central and eastern Amazon and associated anomalous oceanic and atmospheric patterns. International Journal of Climatology, v. 32, n. 8, p. 1193-1205, 2012.

BONINI, I.; RODRIGUES, C.; DALLACORT, R.; MARIMON JUNIOR, B. H.; CARVALHO, M. A. C. Rainfall and deforestation in the municipality of Colíder, southern Amazon. Revista Brasileira de Meteorologia, v. 29, n. 4, p. 483-493, 2014.

BRAZIL. Conselho nacional de recursos hídricos. Secretaria recursos hídricos. Resolução no 32 de 15 de Outubro de 2003. 2003. Available at http://www.cnrh.gov.br. Accessed on 2 Jul. 2016.

CALLEJAS, I. J. A.; DURANTE, L. C.; OliveirA, A. S.; NOGUEIRA, M. C. J. A. Uso do solo e temperatura superficial em área urbana. Mercator - Revista de Geografia da UFC, v. 10, n. 23, p. 207-223, 2011.

CAMARgo, A. P. Balanço hídrico no estado de São Paulo. Technical Bulletin, 116. Campinas, São Paulo: IAC, 1971.

CARMO, A. M. C.; SOUZA-FILHO, P. W. M.; SILVA, J. R. O. Technical report Integration and preliminary interpretation of the weather data generated by the stations of the Itacaiúnas watershed. Projeto Itacaiúnas monitoramento of water resources. Belém, PA: Vale Institute of Technology, 2015.

CARVALHO, L. M. V.; JONES, C.; LIEBMANN, B. The South Atlantic convergence zone: intensity, form, persistence, and relationships with intraseasonal to interannual activity and extreme rainfall. Journal of Climate, v. 17, n. 1, p. 88$108,2004$.

CAVALCANTI, I.; SILVEIRA, V. P.; ALVES, L. M. Caracteristicas atmosfericas e oceanicas em anos de seca. In: BORNA, L. S.; NOBRE, C. A. (Eds.). Secas na Amazônia: causas e consequências. São Paulo, Brazil: Oficina de Textos, 2013, p. 54-77.

CHIODI, A. M.; HARRISON, D. E. 2015-16 El Niño seasonal weather impacts from the OLR event perspective. In: 41st NOAA climate and diagnostics prediction workshop special issue, NWS science \& technology infusion climate bulletin supplement, national weather service. Orono, ME: Office of Science and Technology Integration, 2016, p. 16-20.

COHEN, J. C. P.; BELTRÃO, J. D. C.; GANDU, A. W.; SILVA, R. R. D. Influência do desmatamento sobre o ciclo hidrológico na Amazônia. Ciência e Cultura, v. 59, n. 3, p. 36-39, 2007.

CORREIA, F. W. S.; ALVALÁ, R. C. S.; MANZI, A. O. Modeling the impacts of land cover change in Amazonia: a regional climate model (RCM) simulation study. Theoretical and Applied Climatology, v. 93, n. 3-4, p. 225-244, 2008.

CORREIA, F. W. S.; MANZI, A. O.; CÂNDIDO, L. A.; SANTOS, R. M. N. D.; PAULIQUEVIS, T. Balanço de umidade na Amazônia e sua sensibilidade às mudanças na cobertura vegetal. Ciência e Cultura, v. 59, n. 3, p. 39-43, 2007. 
CRUZ, D.; PANAACHUK, L. Saga e persistência: a histórica formação do sudeste do Pará desde os tempos (mais) antigos. 2014. Available at http://www.scientiaconsultoria.com.br/site2009/pdf/estudos/Panachuk_2014_S aga_e_persiste.pdf. Accessed on 10 May. 2018.

DE SOUZA, E. B.; AMBRIZZI, T. ENSO impacts on the South American rainfall during 1980s: Hadley and Walker circulation. Atmósfera, v. 15, n. 2, p. 105120, 2002.

DE SOUZA, E. B.; FERREIRA, D. B. D. S.; GUiMARÃES, J. T. F.; FRANCO, V. D. S.; AZEVEDO, F. T. M. D.; MORAES, B. C. D.; DE SOUZA, P. J. D. O. P. Padrões climatológicos e tendências da precipitação nos regimes chuvoso e seco da Amazônia oriental. Revista Brasileira de Climatologia, v. 21, p. 81-93, 2017.

DE SOUZA, E. B.; KAYANO, M. T.; AMBRIZZI, T. Intraseasonal and submonthly variability over the Eastern Amazon and Northeast Brazil during the autumn rainy season. Theoretical and Applied Climatology, v. 81, n. 3-4, p. 177-191, 2005.

DE SOUZA, E. B.; LOPES, M. N. G.; ROCHA, E. J. P. D.; SOUZA, J. R. S. D.; CUNHA, A. C. D.; SILVA, R. R. D.; FERREIRA, D. B. S.; SANTOS, D. M.; CARMO, A. M. C. D.; SOUSA, J. R. A. D.; GUIMARÃES, P. L.; MOTA, M. A. S. D.; MAKINO, M.; SENNA, R. C.; SOUSA, A. M. L.; MOTA, G. V.; KUHN, P. A. F.; SOUZA, P. F. D. S.; VITORINO, M. I. Precipitação sazonal sobre a Amazônia oriental no período chuvoso: observações e simulações regionais com 0 RegCM3. Revista Brasileira de Meteorologia, v. 24, n. 2, p. 111-124, 2009.

FERREIRA, D. B.; DE SOUZA, E. B.; DE MORAES, B. C.; FILHO, L. G. M. Spatial and temporal variability of rainfall in eastern Amazon during the rainy season. The Scientific World Journal, v. 2015, p. 209783, 2015.

FERREIRA, D. B. D. S.; DE SOUZA, E. B.; DE MORAES, B. C. Ciclo horário da precipitação no leste da Amazônia durante o período chuvoso. Revista Brasileira de Climatologia, v. 13, p. 74-86, 2013.

GRIMM, A. M. Interannual climate variability in South America: impacts on seasonal precipitation, extreme events, and possible effects of climate change. Stochastic Environmental Research and Risk Assessment, v. 25, n. 4, p. 537554, 2011.

HASTENRATH, S. Climate dynamics of the tropics. Dordrecht, NL: Kluwer Academic Publishers, 1991.

INMET. Instituto nacional de meteorologia. Normais Climatológicas. 1992. Available at http://www.inmet.gov.br/portal/index.php?R=bdmep/bdmep. Accessed on 15 Oct. 2017.

KAYANO, M. T.; ANDREOLI, R. V.; SOUZA, R. A. F. D.; GARCIA, S. R.; CALHEIROS, A. J. P. El Niño e La Niña dos últimos 30 anos: diferentes tipos. Revista Climanalise. Edição Comemorativa de 30 anos, p. 7-12, novembro, 2016.

LI, W.; ZHANG, P.; YE, J.; LI, L.; BAKER, P. A. Impact of two different types of El Nino events on the Amazon climate and ecosystem productivity. Journal of Plant Ecology, v. 4, n. 1-2, p. 91-99, 2011. 
LOPES, M. N. G.; DE SOUZA, E. B.; FERREIRA, D. B. D. S. Climatologia regional da precipitação no estado do pará. Revista Brasileira de Climatologia, v. 12, n. 1, p. 84-102, 2013.

MARENGO, J. A.; NOBRE, C. A. Clima da Região Amazônica. In: CAVALCANTI, I. F. A.; FERREIRA, N. J.; SILVA, M. G. A. J.; DIAS, M. A. F. S. (Orgs.). Tempo e Clima no Brasil. São Paulo,SP: Oficina de Textos, p. 197-2012, 2009.

MORAES, B. C. D.; COSTA, J. M. N. D.; COSTA, A. C. L. D.; COSTA, M. H. Variação espacial e temporal da precipitação no Estado do Pará. Acta Amazonica, v. 35, n. 2, p. 207-214, 2005.

NOAA. National oceanic and atmospheric administration. 2017. Available at http://www.cpc.noaa.gov/products/analysis_monitoring/ensostuff/ensoyears.sht ml. Accessed on 31 Aug. 2017.

PEREIRA, H. R.; REBOITA, M. S.; AMBRIZZI, T. Características da atmosfera na primavera austral durante o El Niño de 2015/2016. Revista Brasileira de Meteorologia, v. 32, n. 2, p. 293-310, 2017.

PHILANDER, S. G.; HOLTON, J. R.; DMOWSKA, R. El Nino, La Nina, and the Southern Oscillation. San Diego, CA: Academic Press, 1989.

PINHO, O. S.; ORGAZ, M. D. M. The urban heat island in a small city in coastal Portugal. International Journal of Biometeorology, v. 44, p. 198-203, 2000.

PINKAYAN, S. Conditional probabilities of occurence of wet and dry years over a large continental area. Fort Collins, CO: Colorado State University, 1966.

QUADRO, M. F. L. D.; DIAS, M. A. F. D. S.; HERDIES, D. L. Análise de um vórtice ciclônico e mesoescala associado a ZCAS em Janeiro de 2009. Revista Brasileira de Meteorologia, v. 31, n. 3, p. 273-287, 2016.

REBOITA, M. S.; GAN, M. A.; ROCHA, R. P. D.; AMBRIZZI, T. Regimes de precipitação na América do Sul: uma revisão bibliográfica. Revista Brasileira de Meteorologia, v. 25, n. 2, p. 185-204, 2010.

ROCHA, L. M. V.; SOUZA, L. C. L.; CASTILHO, F. J. V. Ocupação do solo e ilha de calor noturna em avenidas marginais a um córrego urbano. Ambiente Construído, v. 11, n. 3, p. 161-175, 2011.

SANTOS, S. R. Q. D.; SILVA, R. B. C. D.; BARRETO, P. N.; NUNES, H. G. G. C.; RODRIGUES, R. D. S.; CAMPOS, T. L. D. O. B. Regime térmico e hídrico do solo para área de floresta tropical em anos de El Niño e La Niña, Caxiuanã-PA: estudo de caso. Revista Brasileira de Meteorologia, v. 26, n. 3, p. 367-374, 2011.

SILVA JÚNIOR, R. O.; SOUZA, E. B. D.; TAVARES, A. L.; MOTA, J. A.; FERREIRA, D. B. S.; SOUZA-FILHO, P. W. M.; ROCHA, E. J. P. D. Three decades of reference evapotranspiration estimates for a tropical watershed in the eastern Amazon. Anais da Academia Brasileira de Ciências, v. 89, n. 3 Suppl, p. 19852002, 2017a.

SILVA JÚNIOR, R. O.; QUEIROZ, J. C. B.; FERREIRA, D. B. S.; TAVARES, A. L.; SOUZA-FILHO, P. W. M.; GUIMARÃES, J. T. F.; ROCHA, E. J. P. Estimativa de precipitação e vazões médias para a bacia hidrográfica do rio Itacaiúnas (BHRI), Amazônia Oriental, Brasil (Estimation of precipitation and average flows for the 
itacaiúnas river watershed (IRW) - Eastern Amazonia, Brazil). Revista Brasileira de Geografia Física, v. 10, n. 5, p. 1638-1654, 2017b.

SODRE, G. R. C.; DE MORAES, B. C.; FERREIRA, D. S.; OLIVEIRA, J. V.; SOUZA, E. B. Teleconexões oceânicas nos padrões climatológicos da Amazônia oriental: análise dos últimos 40 anos (1974-2013). Revista Brasileira de Climatologia, v. 17 , p. 52-66, 2015.

SOUSA, A. M.; ROCHA, E. J. P.; VITORINO, M. I.; DE SOUZA, P. J. O. P.; BOTELHO, M. N. Variabilidade espaco-temporal da precipitação na Amazônia durante eventos ENOS. Revista Brasileira de Geografia Física, v. 8, n. 1, p. 15$29,2015$.

SOUZA-FILHO, P. W. M.; DE SOUZA, E. B.; SILVA JÚNIOR, R. O.; NASCIMENTO, W. R.; MENDONÇA, B. R. V.; GUIMARÃES, J. T. F.; DALL'AGNOL, R.; SIQUEIRA, J. O. Four decades of land-cover, land-use and hydroclimatology changes in the Itacaiúnas River watershed, southeastern Amazon. Journal of Environmental Management, v. 167, p. 175-184, 2016.

XAVIER, A. C.; KING, C. W.; SCANLON, B. R. Daily gridded meteorological variables in Brazil (1980-2013). International Journal of Climatology, v. 36, n. 6, p. 2644-2659, 2015.

XAVIER, A. C.; KING, C. W.; SCANLON, B. R. An update of Xavier, King and Scanlon (2016) daily precipitation gridded data set for the Brazil. In: Simpósio Brasileiro de Sensoriamento Remoto-SBSR, 18., 2017, São Paulo, Brazil. Anais... São Paulo:INPE Santos, 2017. p. 562-569.

XAVIER, T. D. M. B. S. Tempo de chuva - estudos climáticos e de previsão para o Ceará e nordeste setentrional. Fortaleza-Ceará, Brazil: ABC Editora, 2001.

XAVIER, T. D. M. B. S.; XAVIER, A. F. S. Classificação e monitoração de períodos secos ou chuvosos e cálculo de índices pluviométricos para a região Nordeste do Brasil. Revista Brasileira de Engenharia, v. 5, n. 2, p. 7-31, 1987.

XAVIER, T. D. M. B. S.; XAVIER, A. F. S. Caracterização de períodos secos e ou excessivamente chuvosos no Estado do Ceará através da técnica dos quantis: 1964-1998. Revista Brasileira de Meteorologia, v. 14, n. 2, p. 63-78, 1999.

XAVIER, T. D. M. B. S.; XAVIER, A. F. S.; ALVES, J. M. B. Quantis e eventos extremos: aplicações em ciências da terra e ambientais. Fortaleza, Brazil: RDS, 2007.

XAVIER, T. M. B. S.; SILVA, J. F.; REBELLO, E. R. G. A técnica dos quantis e suas aplicações em meteorologia, climatologia e hidrologia, com ênfase para as regiões Brasileiras. Brasília, Brazil: Thesaurus Editora de Brasília Ltd., 2002. 